\title{
PENGARUH PENGGANTIAN SEBAGIAN CAMPURAN TEPUNG IKAN DENGAN AMPAS KECAP DALAM PAKAN IKAN TERHADAP PENINGKATAN KADAR PROTEIN IKAN KERAPU MACAN
}

\author{
I.A.Kd.Juli Andayani \\ Universitas Pendidikan Ganesha \\ Singaraja, Indonesia \\ e-mail: andayani00@gmail.com
}

\begin{abstract}
Abstrak
Penelitian ini bertujuan untuk mengetahui pengaruh penggantian sebagian campuran tepung ikan dengan ampas kecap dalam pakan ikan terhadap peningkatan kadar protein ikan kerapu macan ( Epinephelus fuscoguttatus ). Subyek yang digunakan dalam penelitian ini adalah ikan kerapu macan Epinephelus fuscoguttatus ) sebanyak 3 ekor yang ditempatkan pada masing - masing bak polikarbonat yaitu bak A dan bak B. Bak A merupakan kelompok eksperimen, dimana pada bak $A$, ikan diberikan pakan jenis 1 milai hari 1 - hari 30 , setelah hari 30 - hari 42 diberikan pakan jenis 2. Sedangkan bak B merupakan kelompok kontrol. Pada bak $\mathrm{B}$, ikan diberikan pakan jenis 1 mulai dari hari 1 - hari 42 . Setelah pemberian pakan, dagung ikan dikerimgkan di dalam fress dryer, lalu dianalisis kadar proteinnya. Penelitian ini merupakan penelitian eskperimen, dimana data yang diperoleh diuji menggunakan statistik parametrik uji - $t$ satu pihak yaitu pihak kanan. Hasil penelitian menunjukkan bahwa ikan kerapu macan ( Epinephelus fuscoguttatus ) yang diberikan pakan jenis 1 mulai dari hari 1 - hari 30, dan pakan jenis 2 mulai dari hari 31 - hari 42 memiliki kadar protein yang lebih besar dari pada ikan kerapu macan yang diberikan pakan kombinasi jenis 1 mulai dari hari 1 - hari 42 . Ini berarti bahwa penggantian sebagian campuran tepung ikan dengan ampas kecap dalam pakan ikan dapat meningkatan kadar protein dari ikan kerapu macan (Epinephelus fuscoguttatus ).
\end{abstract}

Kata kunci: Tepung Ikan, Ampas Kecap, Pakan Ikan, Kadar Protein

\section{Pendahuluan}

Pakan merupakan istilah yang tidak asing lagi bagi dunia perikanan dan peternakan. Pakan ikan adalah makanan ikan. Pakan merupakan faktor utama yang menentukan pertumbuhan dan meningkatkan nilai gizi ikan. Pakan ikan merupakan campuran dari berbagai bahan pangan baik nabati maupun hewani, yang diolah sedemikian rupa sehingga mudah dimakan dan sekaligus merupakan sumber nutrisi bagi ikan. Pakan dapat dibedakan menjadi dua berdasarkan sumbernya, yaitu: pakan alami dan pakan buatan. Menurut fungsinya, pakan dapat dikelompokkan menjadi dua golongan, yaitu: sebagai pakan utama, apabila sebagian besar sumber energi yang dibutuhkan ikan berasal dari pakan yang diberikan; dan pakan tambahan, apabila hanya sebagian sumber energi yang dibutuhkan dipenuhi dari pakan yang diberikan.Pakan yang diberikan kepada ikan harus memenuhi aspek fisik, aspek biologi, aspek kimiawi yang banyak berhubungan dengan nilai gizi dan aspek pengelola pembenihan sendiri.

Pakan merupakan makanan bagi ikan. Pakan ikan adalah makanan yang khusus dibuat atau diproduksi agar mudah dimakan dan dicerna dalam proses pencernaan ikan sehingga menghasilkan energi yang dapat dipergunakan untuk aktivitas hidup. Ketersediaan pakan berpengaruh besar terhadap pertumbuhan dan kelangsungan hidup ikan. Jumlah pakan yang dibutuhkan oleh ikan setiap harinya berhubungan erat dengan ukuran berat dan umur ikan. Rata-rata jumlah pakan harian yang dibutuhkan oleh seekor ikan adalah sekitar $3-4 \%$ dari berat total badannya (biomass ) (Siregar, Abas. 1995 ). Faktor yang dapat menentukan kebutuhan pakan harian adalah perbedaan lingkungan, yaitu : suhu air, kandungan oksigen terlarut, dan agresivitas ikan untuk mendapatkan pakan.

Tepung ikan merupakan bahan dasar pembuatan pelet (pakan buatan). Tepung ikan berasal dari ikan rucah. Tepung ikan memiliki kandungan zat -zat gizi penting yang sangat diperlukan oleh ikan, baik untuk pertumbuhan maupun untuk menghasilkan energi. Kandungan zat -zat gizi tepung ikan adalah 22,65 \% protein; 15,38 \% lemak; $26,65 \%$ abu; $1,80 \%$ serat; 
dan 10,72 \% air (Mujiman,Ahmad. 1984). Ampas kecap adalah buangan dari proses pembuatan kecap yang kandungan nutrisinya cukup baik untuk dijadikan sebagai pakan alternatif. Kandungan nutrisi ampas kecap dapat dilihat pada Tabel 2.1. Menurut Reksohardiprodjo (1990) dalam Cahyono (2003), ampas kecap memiliki kandungan asam amino yang cukup lengkap.

Menurut Davy dan Chournard (1980), ikan membutuhkan protein, lemak, karbohidrat, vitamin dan mineral sebagai sumber nutrien dalam pakannya. Masing - masing memiliki fungsi yang berbeda. Salah satu nutrien yang penting adalah protein. Protein sangat diperlukan oleh ikan karena, protein sangat penting dalam pembentukan sel - sel baru pada ikan yang sedang tumbuh. Apabila organisme kekurangan energi, maka protein dapat digunakan sebagai sumber energi. Hal ini yang menyebkan pentingnya suplay protein dalam pakan secara terus menerus (Wilson, 1984 dalam Steffens, 1989).

Kandungan protein dalam pakan yang akan diberikan kepada ikan yang dapat meningkatkan nilai gizi dari ikan. Jenis bahan yang memiliki kandungan nutrisi pakan yang lengkap dan dibutuhakan oleh ikan adalah tepung ikan. Selama ini tepung ikan dijadikan sebagai bahan dasar pembuatan pelet (pakan buatan). Kandungan zat gizi tepung ikan adalah: $22,65 \%$ protein; 15,38\%lemak; 26,65\% abu ; 1,80\% serat, dan 10,72\% air (Mujiman,Ahmad. 1984).

Harga tepung ikan di pasaran sangat mahal, sehingga perlu dicarikan bahan alternatif untuk mengganti atau sebagai campuran tepung ikan dalam pakan. Bahan alternatif yang dipilih tentunya harus memiliki kandungan zat gizi penting yang diperlukan oleh ikan. Salah satunya adalah ampas kecap. Ampas kecap memiliki kandungan zat gizi penting yang di perlukan oleh ikan. Kandungan zat gizi ampas kecap adalah: 39,1\% protein ; $17,4 \%$ lemak ; $6,1 \%$ abu ; 15,9\% serat; dan 9\% air (Marzuki,M. 2001). Ampas kecap yang digunakan sebagai pengganti campuran tepung ikan dalam pakan diharapkan mampu meningkatkan nilai gizi ikan terutama nilai proteinnya.

Ikan yang memiliki prospek pasar cukup baik adalah ikan kerapu macan (Epinephelus fuscoguttatus). Hal ini dilihat dari permintaan ekspor kerapu macan yang terus meningkat dari tahun ke tahun (Siti,AR. 2001). Parameter ekologis yang cocok bagi kehidupan kerapu macan yaitu suhu berkisar antara $25-30^{\circ} \mathrm{C}$ dan salinitas antara $33-35$ ppt (Tawada, 1989). Ikan kerapu macan saat ini sedang dikembangkan di BBRPBL - Gondol. Berdasarkan uraian di atas, maka dilakukan penelitian tentang pengaruh penggantian sebagian campuran tepung ikan dengan ampas kecap dalam pakan ikan terhadap peningkatan kadar protein ikan kerapu macan (Epinephelus fuscoguttatus).

\section{Metode}

Penelitian ini merupakan penelitian eksperimen yang bertujuan untuk mengetahui pengaruh penggantian sebagian campuran tepung ikan dengan ampas kecap dalam pakan ikan terhadap peningkatan kadar protein ikan kerapu macan (Epinephelus fuscoguttatus ). Penelitia ini dilakukan di BBRPBL - Gondol, selama 2 bulan yaitu 2 Mei - 2 Juli. Pada penelitian ini, diasumsikan bahwa (1) kedua bak polikarbonat yang digunakan dalam penelitian ini memiliki kondisi yang sama dalam hal suhu air, stadia ( ukuran ikan ), kandungan oksigen terlarut dan feeding rate, (2) ukuran ikan yang sama memiliki berat yang sama. Subjek yang digunakan adalah Ikan kerapu macan (Epinephelus fuscoguttatus). Penelitian ini diawali dengan mempersiapkan bak polikarbonat, pakan, ikan alat dan bahan. Pada penelitian ini digunakan dua bak, yaitu: satu bak sebagai kelompok kontrol dan bak ke dua sebagai kelompok eksperimen. Ikan kerapu macan (Epinephelus fuscoguttatus ) pada kedua bak diberikan pakan dengan jenis berbeda. Setelah pemberian pakan, daging ikan kerapu macan dfiambil dan dikeringkan di dalam fress dryer. Setelah kering, dilakukan penimbangan daging ikan untuk analisis kadar protein pada ikan kerapu macan tersebut. Alat yang digunakan untuk analisis kadar protein adalah set alat desrtuksi, set alat destilasi, dan set alat titrasi.

Data yang diperoleh adalah kadar protein dari ikan kerapu macan (Epinephelus fuscoguttatus ) yang diberikan jenis pakan yang berbeda.

Teknik pengumpulan data yang dilakukan dalam penelitian ini meliputi 2 tahap, yaitu: tahap persiapan dan tahap pelaksanaan. 


\section{Tahap Persiapan}

Pada tahap ini, ada beberapa hal yang dipersiapkan yaitu : bak polikarbonat, pakan, ikan, alat dan bahan. Penelitian ini dilakukan pada bak polikarbonat sebanyak 2 buah dengan sistem air mengalir yaitu bak A dan bak B. Pada masing - masing bak terdapat 12 ekor ikan yang berukuran antara $3-12 \mathrm{~cm}$.

Pada bak $A$, ikan diberikan pakan jenis 1 mulai hari 1 - hari 30 , dan pada hari 31 sampai hari 42 diberikan pakan jenis 2 . Sedangkan pada bak $B$, ikan hanya diberikan pakan jenis 1 mulai hari 1 - hari 42. Pakan kombinasi jenis 1 dan jenis 2 dapat dilihat pada Lampiran 1. Setelah hari 42 pemberian pakan dihentikan. Selanjutnya pada masing - masing bak diambil 3 ekor ikan dengan ukuran $3 \mathrm{~cm}$ untuk ditentukan kadar proteinnya. Sebelum dianalisis kadar proteinnya, daging ikan dikeringkan dalam fress dryer.

\section{Tahap Pelaksanaan}

Analisis kadar protein dari ikan kerapu macan ( Epinephelus fuscoguttats ) dilakukan dengan metode kjeldhal.

Rumus yang digunakan untuk menghitung kadar protein ikan kerapu macan dengan metode kjedhal adalah :

$$
\begin{aligned}
& \qquad \frac{14,01 \times 0,2 \times 6,25 \times(\text { ml titrasi sampel }- \text { ml titrasi blanko })}{m g r \text { sampel }} \times 100 \\
& (\text { Protein }= \\
& (\text { Marzuki,M. 2001) }
\end{aligned}
$$

Data kadar protein ikan kerapu macan diuji menggunakan statistik parametrik $\mathrm{t}$ - test yaitu uji satu pihak ( pihak kanan ).

\section{Hasil dan Pembahasan}

Hasil yang diperoleh dalam penelitian ini adalah kadar protein ikan kerapu macan (Epinephelus fuscoguttatus ) pada dua bak polikarbonat yang diberikan pakan jenis berbeda. Hasil penelitian ini disajikan pada tabel 1.

Tabel 1. Kadar Protein Ikan Kerapu Macan (Epinephelus fuscoguttatus )

\begin{tabular}{ccc}
\hline Bak & Subjek & Kadar protein \% \\
\hline \multirow{2}{*}{ A } & 1 & 45,66 \\
& 2 & 45,70 \\
& 3 & 45,90 \\
B & 1 & 44,16 \\
& 2 & 44,32 \\
& 3 & 42,95 \\
\hline
\end{tabular}

Dari analisis data yang telah dilakukan dengan uji satu pihak, yaitu pihak kanan, diperoleh bahwa Ho ditolak dan Hi diterima. Ini berarti bahwa penggantian sebagian campuran tepung ikan dengan ampas kecap dalam pakan ikan dapat meningkatkan kadar protein dari ikan kerapu macan (Epinephelus fuscoguttatus). Perbedaan kadar protein tersebut disebabkan oleh kombinasi pakan yang diberikan, dimana dalam pakan jenis 2 terdapat tepung ampas kecap yang digunakan sebagai pengganti sebagian campuran tepung ikan dalam pakan, sedangkan dalam pakan jenis 1 tidak terdapat tepung ampas kecap.

Ampas kecap yang digunakan sebagai pengganti sebagian campuran tepung ikan dalam pakan ikan dapat meningkatkan kadar protein dari ikan kerapu macan (Epinephelus fuscoguttatus) karena, ampas kecap memiliki kandungan nutrisi cukup lengkap. Adapun kandungan nutrisi dari ampas kecap adalah : 39,1\% protein; $17,4 \%$ lemak; $6,1 \%$ abu; 15,9 \% serat dan $9 \%$ air (Marzuki, M. 2001). Disamping itu, ampas kecap memiliki kandungan asam amino esensial dan non esensial (Cahyono, 2003). Kandungan asam amino ampas kecap akan mempengaruhi mutu atau kualitas protein karena, mutu protein dipengaruhi oleh sumber asalnya serta kandungan asam aminonya, selain itu jenis dan komposisi asam amino dari suatu 
bahan menjadi faktor penentu kualitas proteinnya. Sehingga kadar protein yang terkandung pada ikan kerapu macan menjadi lebih besar dan mutu atau kualitasnya menjadi lebih bagus.

Ikan kerapu macan (Epinephelus fuscoguttatus) merupakan ikan karnivora yang makanan pokoknya berasal dari bahan pangan yang banyak mengandung sumber nutrisi hewani. Dalam penelitian ini sumber nutrisi yang diberikan adalah tepung ikan karena, tepung ikan memiliki kandungan nutrisi lengkap dan sangat dibutuhkan untuk pertumbuhan ikan. Kandungan gizi dari tepung ikan adalah : 22,65\% protein; 15,38 \% lemak; 26,65 \% abu; 1,80\% serat dan 10,72\% air (Mujiman, Ahmad. 1984). Dari kandungan gizi tepung ikan itu dapat dilihat bahwa kandungan proteinya sebesar $22,65 \%$. Sedangkan kandungan protein ampas kecap sebasar $39,1 \%$. Dari perbandingan kandungan protein ampas kecap dengan tepung ikan dapat dilihat bahwa ampas kecap memiliki kandungan protein yang lebih besar dari tepung ikan, hal ini juga yang menyebabkan perbedaan kadar protein pada ikan kerapu macan tersebut.

\section{Simpulan dan Saran}

Dari penelitian yang telah dilakukan maka, dapat disimpulkan bahwa penggantian sebagian campuran tepung ikan dengan ampas kecap dalam pakan ikan dapat meningkatkan kadar protein dari ikan kerapu macan (Epinephelus fuscoguttatus ). Saran yang dapat dipetik dari penelitian ini bagi para peneliti adalah : (1) Peneliti yang ingin melakukan penelitian yang berhubungan dengan peningkatan kadar protein dari ikan kerapu (Epinephelus $s p$ ) sebaiknya diperhatikan kombinasi pakan yang diberikan, (2) peneliti yang ingin melakukan penelitian yang berhubungan dengan pemilihan bahan alternatif sebagai pengganti atau campuran tepung ikan dalam pakan, banyak pilihannya misalnya : bungkil kedelai , dedak, beras, jagung dll, (3) peneliti yang ingin melakukan penelitian yang sama harus diperhatikan feeding rate, suhu dan kandungan oksigen terlarutnya.

\section{Daftar Pustaka}

Mudjiman,Ahmad. 1984. Makanan Ikan. Sitobondo : Penebar Swadaya

Marzuki,M. dkk. 2001. Pengaruh Kandungan Protein TerhadapPertumbuhan Juvenil Kerapu Macan. Gondol : BBRPBL

Isnansetyo,Alim dan Kurniastuty. 1995. Pakan Alami Untuk Pembeniha Organisme Laut. Yogyakarta : Kanisius

Siregar,Abas . 1995. Pakan Ikan Alami. Yogyakarta : Kanisius.

Kelompok Kerja Nutrisi. 2001. Penerapan Teknologi Nutrisi dan Pakan Pada Pengembangan Budidaya Kerapu Tikus (Cromileptes altivelis ). Gondol : BBRPBL

Aliah,RS, dkk. 2001. Lokakarya Nasional Pengembangan Agribisnis Kerapu. Jakarta : BPPT

Subyakto,Slamet. 2001. Pemanfaatan Bungkil Kedelai Sebagai Sumber Protein Pakan Ikan Kerapu Tikus ( Cromileptes altivelis ). Gondol : BBRPBL

Neltje, NP, dkk. 2001. Kebutuhan Protein dan Pemanfaatan Bahan Baku Lokal Sebagai Sumber Protein dalam pembesaran Kerapu Bebek (Cromileptes altivelis). Gondol : BBRPBL

Winarno,FG. 1992. Kimia Pangan dan gizi. Jakarta : Gramedia Pustaka Utama

Sudarmaji,Slamet, dkk. 1989. Analisa Bahan Makanan dan Pertanian. Yogyakarta : Liberti dan UGM

Chumadi,dkk. 1992. Pedoman teknis budidaya pakan alami. Jakarta: Badan Penelitian dan Pengembangan Pertanian Departemen Pertanian. 